\title{
Comparison of Strength Between Laterite Soil and Clay Compressed Stabilized Earth Bricks (CSEBs)
}

\author{
Abd Halid Abdullah ${ }^{1, *}$, Sasitharan Nagapan ${ }^{1}$, Anna Antonyova ${ }^{2}$, Kannan Rasiah $^{3}$, \\ Riduan Yunus ${ }^{1}$, and Samiullah Sohu ${ }^{1}$ \\ ${ }^{1}$ Faculty of Civil and Environmental Engineering, UniversitiTun Hussein Onn Malaysia, 86400 \\ ParitRaja, BatuPahat, Johor, Malaysia \\ ${ }^{2}$ Faculty of Management, University of Prešov in Prešov, Prešov 08001, Slovak Republic \\ ${ }^{3}$ Department of Mechanical Engineering, Politeknik Port Dickson, Negeri Sembilan, Malaysia
}

\begin{abstract}
Compressed Stabilized Earth Brick (CSEB) is a sustainable material utilizing locally available soils mixed with stabilizers to increase its strength. Two main factors affecting the strength of prototype are its compressive strength and water absorption rate. In this study, the mix proportion ratio for producing CSEB prototypes from laterite soil and clay types was 1:10 (cement:soil). Three different compactions (i.e. 2000, 3000 , and $4000 \mathrm{Psi}$ ) were applied to produce prototypes with dimension of $100 \times 50 \times 40 \mathrm{~mm}$. The samples were tested at the ages of 7 and 28 days. For laterite soil CSEB, the optimum strength was achieved by the sample subjected to 2000 Psi compaction,withits compressive strength of 9.0 $\mathrm{N} / \mathrm{mm}^{2}$ and water absorption rate of $14.9 \%$. For clay CSEBthe optimum strength observed was the sample subjected to 4000 Psicompaction, with the compressive strength of $5.8 \mathrm{~N} / \mathrm{mm}^{2}$ and water absorption rate of $17 \%$. However, the compressive strength of clay CSEB is still below the level specified in the MS 76:1972, which is over $7 \mathrm{~N} / \mathrm{mm}^{2}$ for the load-bearing fired brick Class (1). This study also revealed that the increased in compression pressure would result in different strength performances for both CSEBs made from laterite soil and clay.
\end{abstract}

\section{Introduction}

Until recently, more than half of the world's population have chosen to build their homes of this soil-based structures due to its high durability, low cost, good resistant to fire and weather factors, and aesthetically attractive [1-5].

Compressed Stabilized Earth Brick (CSEB) is agreen technology in building construction, which has been explored using locally available materials. Soil-based home construction has begun since 1950s in Bogota, Colombia, initially introduced by Raul Ramirez [6]. According to the UNESCO Chair Earthen Architecture [7], clay and laterite soil are suitable to be used in the production of CSEBs, and they are readily available in

\footnotetext{
*Corresponding author: abdhalid@uthm.edu.my
} 
Malaysia [8]. From using manually controlled pressure in a steel mould in early 1950s, the process of producing CSEBs has undergone many changes. In recent years, hydraulic compression machine has been widely used to improve the quality and also to optimize the cost, effort and time in producing CSEBs [9].

Currently in Malaysia, there is no standard in producing CSEB made from laterite soil and clay. Therefore, this study aims at quantifying the compressive strength and water absorption rate of CSEBs made from laterite soil and clay. The values obtained can be used as references and standards in CSEB production in Malaysia.

\section{Overview of CSEB prototype}

Fig. 1 shows a CSEB prototype produced with dimensions of $100 \times 50 \times 40 \mathrm{~mm}$. It resembles an Interlocking Compressed Stabilized Earth Brick (ICSEB) sized $100 \times 125 \times 250 \mathrm{~mm}$ in terms of strength, mixing ratio, and other attributes. The main purpose of producing this prototype brick is to test its compressive strength and water absorption rate.

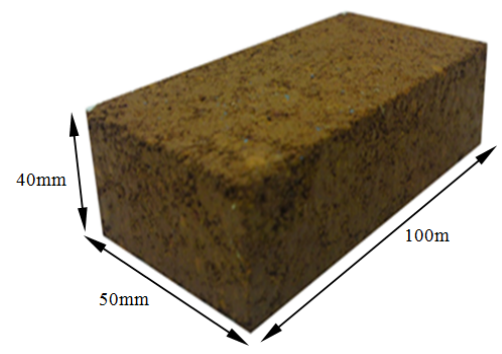

Fig. 1. CSEB prototype dimension.

Soil is the main component for the production of CSEBs [10]. The other ingredients include Ordinary Portland Cement (OPC), sand and water. The properties of the soil and local climatic conditions in a given area should be determined prior to producing CSEB. For instance, dry climatic regions of African continent require different soil than that of tropical climates. Thus, not all types of soil can be used in producing CSEB. Generally soil containing some clay and mud is suitable as it facilitates the adhesion process. The best soil composition contains $15 \%$ gravel, $50 \%$ sand, $15 \%$ silt and $20 \%$ clay [10].

Laterite soil consists of clay and iron particles, and characterized by its hardening properties, chemical content and structural evolution. It is porous and soft at high humidity, where exposing it continuously to high ambient temperatures would cause it to harden [11]. In contrast, clay comprises small pores of air and solid particles with no void spaces. It is also soft at high humidity and will quickly harden if continuously exposed to high ambient temperatures. However, clay has a low shear strength and high compressibility level [11].

Sand is also known as the fine aggregates. For CSEB production, the sand should be reasonably fine (i.e. passing $2 \mathrm{~mm}$ sieve size) as well as clean and free from any organic material as required by the standard. Additional sand will only be required if the percentage of existing sand content is less than one-third of the overall soil quantity [12].

Cement is a good stabilizer in the production of CSEB since it has adhesive properties that bondminerals' particlestogether. In this study, OPC was chosen due to its suitabilityas admixture in the production of soil-based products. Moreover, this type of cement is also highly suitable for use in a variety of climatic conditions [13].

Water must be clean and free from impurities such as organic and sulphate. The presence of impurities will affect the hydration process particularly during the hardening 
stage of the bricks. Whereas, during the curing stage, water is needed for a perfect hydration of cement. The amount of water needed in the mixture is between $10-20 \%$ [11].

\section{Preparation of soil for CSEB}

Laterite soil and clay were selected to be the main ingredients in the production of CSEB prototypes. Theywere taken at a depth of $1.5 \mathrm{~m}$ below ground surface, whereby laterite soil was obtained from a place in Ayer Hitam and clay was acquired from a place in Parit Raja.

The soil samples were analysed and compared with the results found by previous researchers. In particular, analysis results of laterite soil and clay samples were compared with those of Wahab [14] and C.M. Chan [15], respectively. Several tests, which include Particle Distribution Test, Atterberg Limits Test, Chemical Composition Test, and Jar Test, were carried out in accordance to BS 1377:Part 2:1990 [16].

\subsection{Particle distribution test (sieve analysis)}

Most of the mixing ratiosin producing CSEB prototypes consist of aggregated materials, namely soil and sand, which will particularly affect their durability and performance. Sieve test is crucial for obtaining the rate of aggregate mixture of various sizes.

Based on the AURAM Press 3000 [10], soil containing 15\% gravel, 50\% sand, 15\% silt and $20 \%$ clay is considered as having the best soil composition for producing CSEB. Particle Distribution Test on laterite soil found that the percentage of aggregate mixtures of the soil composition were almost similar to those performed by Wahab [14], as outlined in Table 1. These percentages of the composition indicate the suitability of the soil to be used in producing CSEB. For clay, the test results showed that percentage of aggregate mixtures were almost similar to those obtained by C.M. Chan [15]. Apparently, clay composition did not match with that of the best soil composition required for producing CSEB.

Table 1. Soil particle size distribution.

\begin{tabular}{|l|c|c|c|c|c|}
\hline \multirow{2}{*}{ Soil Type } & Place taken from & Clay (\%) & Sand (\%) & Gravel (\%) & Mud (\%) \\
\hline Laterite & Ayer Hitam & 4 & 86 & 10 & - \\
\cline { 3 - 6 } Soil & (Wahab,[14]) & 7.4 & 71.5 & 21.1 & - \\
\hline \hline \multirow{2}{*}{ Clay } & Parit Raja & 25.8 & 0.9 & - & 73.3 \\
\cline { 3 - 6 } & (C.M.Chan, [15]) & 10.23 & 0.57 & - & 89.2 \\
\hline
\end{tabular}

\subsection{Atterberg limits test}

This experiment is carried out to identify and classify soils samples that have been dried, particularlyto determine the value of liquid limit (LL), plastic limit (PL) and the plasticity index (PI) of the soil samples. The determination of these limits is also used to predict the shear strength and soil sedimentation. Both laterite soil and clay samples had passed through $0.425 \mathrm{~mm}$ sieve.

The results of Atterberg limits test as outlined in Table 2 has proven that the laterite soil of Ayer Hitam and clay from Parit Raja to be used in the production of CSEB prototypes in this study are classified as laterite soil and clay. There are obvious similarities in terms of the values for liquid limit (LL), plastic limit (PL) and the plasticity index (PI) of the laterite soil from Ayer Hitam as investigated by Wahab [14], as well as clay from Parit Raja as examined by C.M. Chan [15]. 
Table 2. Atterberg limits.

\begin{tabular}{|l|c|c|c|c|}
\hline \multirow{2}{*}{ Soil Type } & Place taken from & Liquid Limit & Plastic Limit & Plasticity Index \\
& (Researcher) & (LL) (\%) & (PL) (\%) & (PI) \\
\hline Laterite & Ayer Hitam & 43.8 & 22.5 & 21.2 \\
\cline { 3 - 5 } Soil & (Wahab, 2008) & 45.0 & 23.1 & 21.9 \\
\hline \hline \multirow{2}{*}{ Clay } & Parit Raja & 67.5 & 32.04 & 35.5 \\
\cline { 3 - 5 } & (C.M.Chan, 2008) & 68 & 32 & 35 \\
\hline
\end{tabular}

\subsection{Chemical composition test}

In order to run this test, samples of clean soil sized $63 \mu \mathrm{m}$ in the form of dust / dry powder should be prepared. The results of chemical composition analysis, as summarized in Table 3 , found that the content of Silicon Dioxide ( $\mathrm{SiO} 2)$ is the highest within the two types of soil samples, which is $42 \%$ for laterite soil and $60.6 \%$ for clay, respectively. This silica content can help in strengthening the compressive strength of the CSEB prototypes when reacting with cement due topozzolanic process. The high content of lime or Calcium Oxide $(\mathrm{CaO})$ of about $53.6 \%$ in cement, would enhance its performance as binding agent between both soil and sand particles.

Table 3. Material chemical composition (weight percentage).

\begin{tabular}{|l|c|c|c|}
\hline \multicolumn{1}{|c|}{ Types of Chemical } & Laterite Soil (\%) & Clay (\%) & OPC (\%) \\
\hline Carbon dioxide, $\mathrm{CO}_{2}$ & 0.10 & 0.10 & 0.10 \\
\hline Iron (iii) oxide, $\mathrm{Fe}_{2} \mathrm{O}_{3}$ & 19.00 & 6.39 & 5.10 \\
\hline Silicon dioxide, $\mathrm{SiO}_{2}$ & 42.00 & 60.60 & 23.40 \\
\hline Aluminium oxide, $\mathrm{Al}_{2} \mathrm{O}_{3}$ & 35.00 & 22.40 & 10.60 \\
\hline Calcium oxide, $\mathrm{CaO}$ & 0.29 & 0.00 & 53.60 \\
\hline Titanium dioxide, $\mathrm{TiO}_{2}$ & 1.01 & 0.92 & 0.97 \\
\hline Potassium oxide, $\mathrm{K}_{2} \mathrm{O}$ & 1.80 & 2.43 & 0.71 \\
\hline Sulphur trioxide, $\mathrm{SO}_{3}$ & - & 5.63 & 3.76 \\
\hline Sodium oxide, $\mathrm{Na}_{2} \mathrm{O}$ & 0.27 & 0.32 & 0.27 \\
\hline Magnesium oxide, $\mathrm{MgO}$ & 0.21 & 0.88 & 1.15 \\
\hline
\end{tabular}

\subsection{Jar test (sedimentation test)}

Soil is a complex building construction material where each soil sample is different from one to another. The Jar test was carried outto determine the composition and the ratio of soil particles. It was observed that the laterite soil samples obtained from Ayer Hitam contains $75 \%$ sand and $25 \%$ clay. In order to get a good distribution of the particles, the mixture ratio of CSEB prototype should be designed with 1:8:2 (cement:soil:sand). Hence, the existing soil should be added with additional sand as much as $25 \%$ of the amount used. Whereas, the clay samples taken from Parit Raja had approximately $15 \%$ sand and $85 \%$ mud and clay. Since the content of mud and clay is very high, the soil should be modified with mixture ratio of 1:5:5 (cement:soil:sand). This modification is done by adding large quantities of sand to form CSEB prototypes that can withstand compressive stress.

\subsection{Raw materials density}

The density of the raw materials used in the production of CSEB prototypes is determined in accordance to BS 1881:Part 114:1983 [17], and the results are summarized in Table 4. 
Table 4. Density of raw materials.

\begin{tabular}{|c|c|}
\hline Material & Density $\left.\mathbf{( k g} / \mathbf{m}^{\mathbf{3}}\right)$ \\
\hline Water & 1000 \\
\hline Cement & 1095 \\
\hline Laterite Soil & 1286 \\
\hline Clay & 1095 \\
\hline Sand & 1524 \\
\hline
\end{tabular}

\subsection{Sampling and testing of CSEB prototype}

Three different compactions (i.e. 2000, 3000 and 4000 Psi)were considered in the production of CSEB prototypes. As mentioned earlier, the mixture ratios of cement:soil:sand for both types of soil were 1:8:2 for laterite soil, and 1:5:5 for clay, respectively. The raw materials were mixed together manually based on the required mixture ratiosin producing CSEB prototypes with dimension of $100 \times 50 \times 40 \mathrm{~mm}$. The percentage of water required to produce a good mixture is between $10-20 \%$ of the weight of the soils. While mixing, a small portion of this mixture was hand gripped to form a soil ball and then dropped to the ground at a height of one metre. The shape and condition of the fallen soil ball would determine the optimum water content needed. The optimum rate of water content is achieved when the fallen soil ball broke into 4 or 5 fractions on the ground. As a result, the optimum percentage of water required for the mixture was found to be $15 \%$ for laterite soil and $20 \%$ for clay, respectively.

The well-mixed mixture was poured into the mould, and then compacted using a hydraulic compaction machine at three different pressure values of 2000 Psi, 3000 Psi and 4000 Psi. Each prototype sample should be carefully taken out from the mould not to damage its shape at the early stage of production. Each sample should be labelled accordingly to the compaction applied, and subsequently placed in an open area. The curing process was done by spraying each of the prototype samples with water manually every day up to either 7 or 28 days.

CSEB prototype samples were tested for compressive strength and water absorption rate at the age of 7 and 28 days. Universal Testing Machine (UTM) was used for testing compressive strength. For water absorption test, which was based on BS EN 771:Part $1: 2003$ [18], the cooling method was employed where each prototype sample was weighed and dried in an oven for 24 hours at a temperature of $105^{\circ} \mathrm{C}$. The sample was then soaked in water for 24 hours at room temperature. The percentage rate of water absorption was determined by dividing the weight of the sample after immersion with the weight of dry sample, and then multiplied by $100 \%$. Each physical testing of CSEB prototypes was carried out using 3 samples, and the average value of the samples would be considered accordingly as the final value for both compressive strength and water absorption rate.

\section{Results and discussion}

\subsection{Compressive strength}

The CSEB prototype samples produced with different compactions were physically tested through compressive stress test at the age of 7 and 28 days. It was observed that the quantity of laterite soil to be poured into the mould would increase accordingly to the compaction pressures applied. For 2000 Psi compaction, the amount of laterite soil required is $400 \mathrm{~g}$. Whereas, $427 \mathrm{~g}$ and $450 \mathrm{~g}$ of laterite soil were required for compactions of $3000 \mathrm{Psi}$ and 4000 Psi, respectively. 
From Fig. 2(a), it can be seen clearly that the compressive strength of laterite soil CSEB prototype is at its optimum when subjected to 2000 Psi compaction with the strength values increase from $9.0 \mathrm{~N} / \mathrm{mm}^{2}$ for sample age of 7 days to $14.8 \mathrm{~N} / \mathrm{mm}^{2}$ for 28 days old sample. However, as the prototype samples were subjected to compactions of 3000 Psi and 4000 Psi, their compressive strength at 28 days still achieved the predetermined level of strength as stated in MS 76:1972, load-bearing fired brick Class (1), which is at least $7 \mathrm{~N} / \mathrm{mm}^{2}$ [19]. In general, it can be inferred that for all values of compaction pressure applied, the compressive strength of laterite soil CSEB prototypes would be greatly influenced by the age of samples. The increasing age of the samples from 7 days to 28 days would also result in the increase of its compressive strength.

To produce clay CSEB samples, the quantity of clay required to be poured into the mould would increase accordingly to the compaction pressures applied. For 2000 Psi compaction, the amount of clay needed was $410 \mathrm{~g}$. Whereas, $437 \mathrm{~g}$ and $462 \mathrm{~g}$ of clay were required for compactions of 3000 Psi and 4000 Psi, respectively. Since clay has very high percentage of mud content as confirmed by the particle distribution test, it has to be modified by adding sand to the mixture to form a ratio of 1:5:5. It was also observed that laterite soil content is heavier than clay.

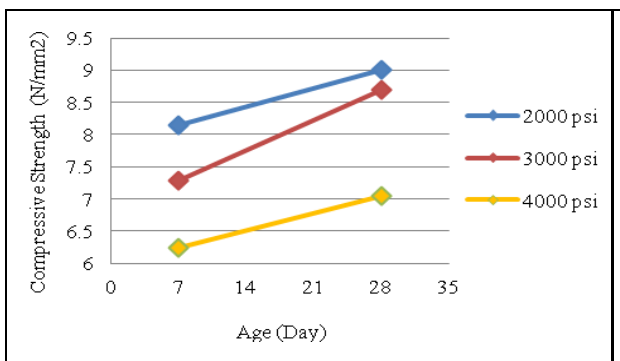

(a) Laterite soil CSEB

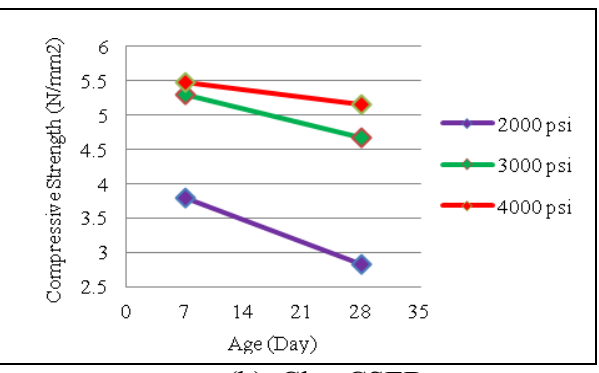

(b) Clay CSEB

Fig. 2. Compressive strength $\left(\mathrm{N} / \mathrm{mm}^{2}\right)$ vs.Age of CSEB prototypes (7 and 28 days).

Fig. 2(b) shows the results of the compressive strength of clay CSEB prototype samples. It can be seen clearly that the increased in compaction pressure applied would result in higher compressive strength. The clay CSEB prototype subjected to compaction of 4000 Psi gave the optimum compressive strength value for 7 days sample. Surprisingly, the value of compressive strength lessened to $5.16 \mathrm{~N} / \mathrm{mm}^{2}$ as the age of the sample increased to 28 days. Generally, it can be presumed that for all values of compaction applied, the compressive strength would reduce with the increasing age of the prototype samples from 7 days to 28 days. Additionally, the compressive strength of clay CSEB prototype is generally below the predetermined level of strength as stated in MS 76:1972 for load-bearing fired brick Class (1), which is at least $7 \mathrm{~N} / \mathrm{mm}^{2}$ [19]. This is due to the fact that clay has a very high mud content; and therefore, could not bear the compressive stress imposed.

\subsection{Water absorption rate}

The results of water absorption rate test on CSEB prototype samples were compared with those of the load bearing fired brick Class (1) based on MS 76:1972 [19]. Although it is not specified in the standard with respect to water absorption rate, the Malaysian construction industry has commonly adopted the absorption rate of less than $15 \%$ for this type of brick. Lower absorption rate indicates better quality bricks and higher resistant to the adverse effects of weather. 
Fig. 3(a) shows the results of the water absorption rate of laterite soil CSEB prototypes. It can be seen clearly from the graph that the increased in compaction would generally result in lower rates of water absorption. Furthermore, for all values of compaction applied, the quality of laterite soil CSEBs improves as their ages increased from 7 days to 28 days as evidenced by lower percentage rate of water absorption. The rate of water absorption is at its optimum when subjected to 4000 Psi compaction with percentage rates dropped down from $15.4 \%$ for sample age of 7 days to $14.5 \%$ for 28 days, respectively. This condition occurs due to the fact that higher compaction applied would make the samples become denser, which in turn preventing the absorption of water.

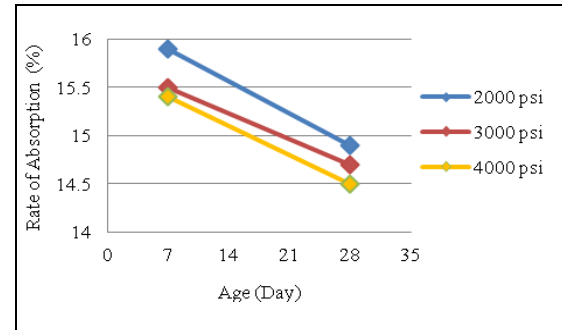

(a) Laterite Soil CSEB

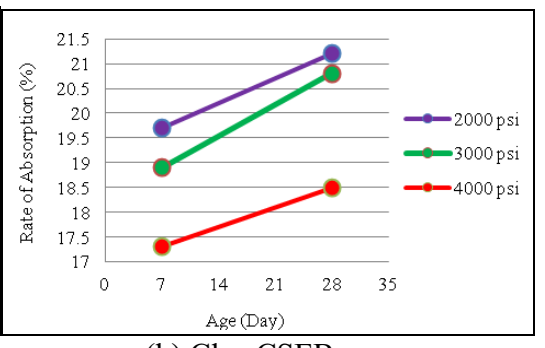

(b) Clay CSEB

Fig. 3. Water absorption rate (\%) vs.Age of CSEB prototypes (7 and 28 days).

Similarly for clay CSEB prototypes, increasing compaction pressures had resulted in lower water absorption rate as shown in Figure 3(b). Apparently, greater compaction applied means heavier compaction of mixture in the mould resulting in a denser sample that prevents the absorption of water. Thus, increasing the curing age of clay CSEBs would result in higher absorption rate. The optimum absorption rate for clay CSEBs was achieved by the sample subjected to 4000 Psi compaction with the values of $17.3 \%$ at the age of 7 days and $18.5 \%$ at 28 days, respectively. However, both values of absorption rate still exceed the allowable limit of $15 \%$. The observation on physical properties found that the prototype will decompose at every verticeswhen touched by hand during the transportation process. It can be inferred that the pozzolanic reaction between aggregates within the content of this prototype is very weak.

\section{Conclusion}

It can be firmly concluded from experimental results that laterite soil is more suitable than clay for CSEB production. It is essential to ensure good distribution of particles during the mixing and compacting processes of producing CSEB. Well-mixed mixture of small and large aggregates can be achieved when the smaller ones filled up the empty spaces in between the larger aggregates. Therefore, mixture ratio of 1:8:2 (cement:soil:sand) was deemed suitable to produce laterite soilCSEBswith 2000 Psi compaction. At this optimum compaction, the aggregate mix remained in its original condition without changing its form. Moreover, all the results of the compressive strength $\left(\mathrm{N} / \mathrm{mm}^{2}\right)$ and water absorption rate (\%) are found to be in accordance with the standards as specified in MS 76:1972 [19].

Our sincere gratitude goes to the staff at Materials Engineering Laboratory, Faculty of Civil and Environmental Engineering, for their tireless assistance during the preparation and testing of samples. I would also like to thank all individuals who have directly or indirectly supported us throughout the course of this study. 


\section{References}

[1] M.R. Jones and A. McCarthy, Preliminary views on the potential of foamed concrete as a structural materials, Magazine of Concrete Research, 7(1), 21-31,(2005)

[2] C. Jayasinghe and N. Kamaladasa. Compressive strength characteristics of cement stabilized rammed earth walls, Univ. of Moratuwa, Sri Lanka, 1978-1976, (2006)

[3] A. H. Abdullah, S.K.A. Bakar and I.A. Rahman, Indoor thermal performance of an office building using conventional brick versus interlocking compressed earth brick (ICEB) wall, Int. J. of Construction Technology and Management, 1(1), 22-27, (2013)

[4] S.K. Abu Bakar and A.H. Abdullah, Simulation of thermal performance in an office, Business Engineering and Industrial Applications Colloquium, IEEE, 318-323, (2012)

[5] N. Ali, N.A. Zainal, M.K. Burhanudin, A.A.A. Samad, N. Mohamad, S. Shahidan and S.R. Abdullah, Physical and mechanical properties of compressed earth brick (CEB) containing sugarcane bagasse ash, MATEC Web Conf., 47, 1-7. (2016)

[6] S. Shahidan, H.B. Koh, A.S. Alansi and L.Y. Loon, Strength development and water permeability of engineered biomass aggregate pervious concrete, MATEC Web Conf., 47, 2-7, (2016)

[7] V. Rigassi and P. OdulCRATerre-EAG, Compressed earth blocks: Manual of production, Vol. I: Manual of production, A Publication of The Deutsches Zentrum fur Entwicklungs technologien-GATE, 6, (1985)

[8] UNESCO Chair Earthen Architecture, Compressed stabilized earth block, Auroville Earth Institute, (2010).

[9] M.A. Yahaya, Mengkaji penggunaan tiang kapur terhadap enapan tanah bukan berstruktur kejuruteraan, Final Year Project Thesis, Universiti Teknologi Malaysia, (2008)

[10]H. Guillaud, T. Joffroy OdulCRATerre-EAG, Compressed Earth Blocks: Manual of design and construction, Vol. II: Manual of design and construction, A publication of The Deutsches Zentrum fur Entwicklungs technologien-GATE, 8, (1985)

[11]AURAM Press 3000 (2010), Assessed on 18th October 2016, http://www.aureka.com/earth-construction-equipment/auram-press-3000

[12] M. Shariman, Pembaikan tanah liat marin dengan pendekatan saliran pugak, Final Year Project Thesis, UniversitiTeknologi Malaysia, (2008)

[13]A. Bush, Understanding stabilized earth construction, Wilson Boulevard, Suite 500 Arlington, Virginia, USA, (1984)

[14]M. Tarmizi, Pengaruh pasir, kandungan simen dan kaedah pengawetan terhadap konkrit ringan berudara, Final Year Project Thesis, UniversitiTeknologi Malaysia, (2006)

[15] G.O. Adeyemi and K.A. Wahab, Variability in the geotechnical properties of a lateritic soil from south western Nigeria, Bulletin of Engineering Geology and the Environment,67(4), 579-584, (2008)

[16]C.M. Chan and R. Robani, Alternative aggregates from Clay-POC: An exploratory study, UniversitiTun Hussein Onn Malaysia, ICCBT 2008-A-(38), 423-432, (2008).

[17]BS 1377:Part 2:1990, Methods of test for soils for civil engineering purposes, British Standard Institute, London, United Kingdom, (1990)

[18]BS 1881: Part 114:1983, Methods for determination of density of hardened concrete, British Standard Institute, London, United Kingdom, (1983)

[19]BS EN 771:Part1:2003, Specification for masonry units. Clay masonry units, British Standard Institute, London, United Kingdom, (2003)

[20]MS 76:1972, Specification for bricks and blocks of fired Brick earth, clay or shale, Part 2: Metric units, Malaysia Standard, 22, Malaysia,(1972) 